\title{
Tradition and its 'use': the ethics of theological retrieval
}

\author{
Simeon Zahl \\ Faculty of Divinity, University of Cambridge, Cambridge CB3 9BS \\ smz21@cam.ac.uk
}

\begin{abstract}
This article argues for the importance of attending to the subjective dynamics involved in retrieval of past theological traditions for contemporary purposes. Building on a close analysis of Martin Luther's distinction between the 'substance' of a thing and its 'use', the article makes a theological case for the importance of attending not just to what we retrieve from tradition, but also to how and why we retrieve it. Analysis of Luther's distinction suggests (1) that the meaning of theological claims remains unexpectedly fluid until such claims have been located within the ethical drama of 'use', and (2) that one of the best ways to get theological traction on the dynamics of 'use' is to attend to the affective economies in which theological reasoning is always located. It concludes by drawing attention to specific areas in contemporary ethics where new light can be shed through attention to the dynamics of 'use'.
\end{abstract}

Keywords: affective economies, Martin Luther, theological retrieval, use/substance distinction

In academic theology as it is practised today, to speak about the importance of 'tradition' as a theological resource can be to risk banality. There is very little contemporary theology from any confessional background that does not go about its business through some kind of close engagement with an existing deposit of Christian texts and practices. Such engagement can be critical, or constructive, or reparative in how it approaches the artefacts of existing Christian reflection. It can focus, in theory, on any era other than the immediate present, and it can engage with lost and marginalised counter-traditions from Christianity's long past rather than just with traditionally dominant or otherwise 'classic' voices. ${ }^{1}$ We all have traditions we seek to advocate or rehabilitate, and, arguably we all also have

${ }^{1}$ For a helpful analysis of theological retrieval as it has been practised in recent theology, see Darren Sarisky, 'Tradition II: Thinking with Historical Texts: Reflections on Theologies of Retrieval', in Darren Sarisky (ed.), Theologies of Retrieval: An Exploration and Appraisal (London: T\&T Clark/Bloomsbury, 2017). 
counter-traditions from which we are trying to extricate ourselves to one degree or another.

To put this more concretely: a very large part of the work that has shaped the field of Christian theology in recent decades has been produced through direct formal engagement, both constructive and critical, with deposits from the Christian past. We might think of Lewis Ayres' and Khaled Anatolios' interventions in recent trinitarian debates via extended analyses of patristic theologies, ${ }^{2}$ or of the ongoing ecumenical influence of de Lubac and Daniélou's strategy of ressourcement, ${ }^{3}$ or of Kathryn Tanner's drawing on figures like Gregory of Nyssa to address contemporary debates about salvation, nature and grace, ${ }^{4}$ or of J. Kameron Carter's reading of antebellum Afro-Christian writers like Briton Hammon and Jarena Lee to bring to light the racial logics underpinning modern theology. ${ }^{5}$ When A. N. Williams argues that "The purpose of engaging older theology is ... to inspire, to provoke theological imagination to new insight', such that theology might 'flower beyond [older tradition] as the very consequence of engaging with it', ${ }^{6}$ it is difficult to imagine many contemporary theologians disagreeing with this claim.

In reflecting on constructive 'retrieval' of past tradition for contemporary theological purposes, the interesting question is therefore not whether we should do it, but how we should do it, and whether there are any particular problems or dynamics we need to be aware of in doing so in order to make sure that we do it well.

In this article, I want to explore one particular set of dynamics which is at work whenever theologians draw on tradition today, but which often goes unexamined: namely, the process by which theologians come to be drawn to the particular retrievals in which they become engaged. My interest in what follows is in the subjectivity of the theologian as she engages with tradition, and in the affective and desiderative factors that resource as well as distort such engagement. Although the value of constructive retrieval of past tradition by no means reduces to such dynamics - theology is not resolvable into

2 Lewis Ayres, Nicaea and its Legacy: An Approach to Fourth-Century Trinitarian Theology (Oxford: OUP, 2004); Khaled Anatolios, Retrieving Nicaea: The Development and Meaning of Trinitarian Doctrine (Grand Rapids, MI: Baker Academic, 2011).

3 For discussions of the ongoing viability of this strategy, whose impact on the discipline as a whole has been enormous, see A. N. Williams, 'The Future of the Past: The Contemporary Significance of the Nouvelle Theologie', International Journal of Systematic Theology 7 (2005), pp. 347-61; and Gabriel Flynn and Paul D. Murray (eds), Ressourcement: A Movement for Renewal in Twentieth-Century Catholic Theology (Oxford: OUP, 2011).

${ }^{4}$ Kathryn Tanner, Christ the Key (Cambridge: CUP, 2010).

5 J. Kameron Carter, Race: A Theological Account (New York: OUP, 2008).

${ }^{6}$ Williams, 'Future of the Past', p. 351. 
anthropology, and traditions do not simply reduce to the use theologians make of them - nevertheless the effects of personal, communal, material and even biological locatedness are always present in our theological reasoning, and they do more to shape our retrievals than we usually acknowledge.

In what follows I am taking for granted that we never study past Christian traditions neutrally. Rather, we are always 'using' traditions for various reasons that are embedded in our historical and personal context. Some such 'uses' are more or less explicit, as when we draw on tradition to help solve some specific contemporary intellectual or ethical problem, or to persuade others of the problematic character of certain ideas or discourses. Other aspects of the subjective and contextual dynamics shaping our 'use' of traditions, which are often simultaneously at work, are less explicit: for example, when we engage with a traditional figure or text in part to give voice to some specific feeling of anger or injustice or compassion, or to seek approval from a teacher, or even just to make ourselves feel smart. Even when we deploy methods that are specifically designed to help neutralise or at least lessen the effects of our subjectivity on our scholarship - methods which are of course invaluable tools in the scholar's toolkit - it remains the case that the ways that we are drawn to particular questions and topics, and even to 'neutral' or 'objective' methods, are always enmeshed in what Sara Ahmed calls 'affective economies'. ${ }^{7}$ Although there are many good reasons to make use of such methods, it remains the case that if it did not 'feel good' in some way, and in relation to some real or perceived community, to think of oneself as a neutral and objective scholar we would be unlikely to engage in such practices in the first place.

Ayesha Chaudhry, a scholar of Islam, puts it bluntly:

There is no such thing as an objective scholar. Everyone comes to their area of expertise with a set of subjectivities that influence the questions they ask, where they look for answers, who they write to, and how they lay claim to authority.

Crucially, Chaudhry continues, none of this 'necessarily make[s] your scholarship better or worse'. ${ }^{8}$ This is simply a fact on the ground, a

7 Ahmed uses the term 'affective economies' to signify the ways that affects are not simply properties that have 'residence' in individuals, but rather 'work, in concrete and particular ways, to mediate between the psychic and the social, and between the individual and the collective', and thus 'circulate and are distributed across a social as well as psychic field'. See Sara Ahmed, 'Affective Economies', Social Text 79/22 (2004), pp. 119-20.

8 Ayesha Chaudhry, 'Islamic Legal Studies: A Critical Historiography', in Anver M. Emon and Rumee Ahmed (eds), The Oxford Handbook of Islamic Law (Oxford: OUP, 2017), p. 22. 
consequence of the fact that scholars are embodied human beings operating in particular contexts with particular histories. For the purposes of the present article, this also means that these factors related to our subjectivity and positionality are worthy of explicit analysis, both historically and today.

It seems to me that Christian theology has certain especially useful resources for giving us insight into how we might best think about the role of subjectivity in our intellectual work. In what follows, I want to draw on just one such resource: a particular insight from early Protestant theology that I think will give some useful purchase on the question of how to think about how theological tradition comes to be 'used'. Building on an overlooked distinction from Martin Luther's ethics, I will make a theological case for the importance of attending not just to what we retrieve from tradition but also to how and why we retrieve it. As we shall see, analysis of Luther's distinction suggests (1) that the meaning of theological claims remains unexpectedly fluid until such claims have been located within the ethical drama of 'use', and (2) that one of the best ways to get theological traction on the dynamics of 'use' is to attend to the explicit as well as implicit affective dynamics in which the practice of theological reasoning is always embedded.

\section{Luther's use/substance distinction}

The distinction I am referring to is one that Martin Luther often makes in his theology between the 'substance' of a thing (usually substantia, sometimes res) and its 'use' (usus). This is a distinction that appears quite regularly in Luther's writings from 1527 onwards, and much of it is already implied as early as 1515. Although there are passing discussions of the use/substance distinction in the secondary literature, to my knowledge there exists at present no comprehensive examination of this thematic in Luther's thought. ${ }^{9}$

A clear articulation of the use/substance distinction appears in Luther's larger Galatians commentary, where he deploys it to understand the nature of idolatry:

9 For brief discussions see Christoph Henschen, Erniedrigung Gottes und des Menschen Erhoehung (Frankfurt am Main: Peter Lang 2009), pp. 196-204; Gerhard Gloege, Mythologie und Luthertum: Recht und Grenze der Entmythologisierung (Göttingen: Vandenhoeck und Ruprecht, 1963), pp. 143-4; Gerhard Ebeling, 'On the Doctrine of the Triplex Usus Legis in the Theology of the Reformation', in Word and Faith (London: SCM Press, 1963), esp. p. 71; and Christoph Weimer, 'Luther and Cranach on Justification in Word and Image', in Timothy J. Wengert (ed.), The Pastoral Luther (Minneapolis: Fortress Press, 2017), pp. 295-7. 
For the issue is not whether wood is wood or stone is stone, but what is attached to them, that is, how these things are used: whether this wood is God, whether divinity resides in the stone. ${ }^{10}$

What Luther is saying in this passage is that what makes something an idol is not its inherent substance or nature. In fact, all physical idols, like all created things, are ontologically 'good' insofar as they are made of material, like wood or stone, that has been created by God. Rather, what matters, theologically and ethically, is the use we make of them. An idol is not an idol inherently; rather, it becomes one through how it is 'used'.

The context for this claim is a critique of Aristotle's understanding of the metaphysical importance of 'substances', as it had been mediated to Luther in scholastic theology. ${ }^{11}$ Luther is responding to an ontological tradition that holds that you know most of what you need to know about a thing, including theologically, when you know about its substance, because this tells you what it can do and what it is for. As early as 1515, Luther had critiqued this idea, arguing instead that what is theologically decisive about a thing is its relations to things outside of it, not its inherent being or nature. ${ }^{12}$

${ }^{10}$ LW 26, p. 92; WA 40/I, p. 170; emphasis added.

11 On Luther's engagement with Aristotelian metaphysics, including his engagement with Aristotle's various scholastic interpreters, see Theodor Dieter, Der junge Luther und Aristoteles: Eine historisch-systematische Untersuchung zum Verhältnis von Theologie und Philosophie (Berlin: Walter de Gruyter, 2001), esp. pp. 234-50.

12 As Luther puts it in a much-discussed comment in the Dictata super Psalterium, “"substance" [substantia] properly is a quality or something from the outside rather than from the very being of a thing. For Scripture is not interested in the quiddities of things, but only in their qualities' (LW 10, p. 356; WA 3, p. 419). According to Gerhard Ebeling, what Luther means by this is that the term 'substance' needs to be reinterpreted to signify 'not the nature of a thing in and for itself, but rather what it signifies to the person engaging with it, that is, what the person takes it to be, and how he understands his relation to it' (Gerhard Ebeling, 'Die Anfänge von Luthers Hermeneutik', in Lutherstudien I (Tübingen: Mohr-Siebeck, 1971), p. 24). In Ebeling's interpretation, this early claim about substances entails one of the most fundamental metaphysical breaks between Luther and late medieval theology, and becomes determinative of much of his thought. For further discussion of Ebeling's interpretation of the significance of this break, which has been criticised by Ruokanen, Juntunen and Peura, among others, esp. in relation to the ontology of the person, see Miikka Ruokanen, 'Das Problem der Gnadenlehre in der Dogmatik Gerhard Ebelings', Kerygma und Dogma 35 (1989); Sammeli Juntunen, 'Luther and Metaphysics: What is the Structure of Being according to Luther?', in Carl E. Braaten and Robert W. Jenson (eds), Union with Christ: The New Finnish Interpretation of Luther (Grand Rapids, MI: William B. Eerdmans, 1998); and Simo Peura, Mehr als ein Mensch? Die Vergöttlichung als Thema der Theologie Martin Luthers von 1513 bis 1519 (Mainz: Verlag Philipp von Zabern, 1994), pp. 79-85. Regardless of whether Ebeling is entirely right about Luther's theology 
This argument develops more precisely in Luther's mature work into the distinction between the substance of a thing and how it is used.

A particularly clear exposition of the use/substance distinction can be found in Luther's 1528/9 notes on Deuteronomy 4:15-17, where Moses talks about idolatry and images:

The issue is not about the substance of a thing, but about its use or abuse. Our preaching is not about the nature of a thing in itself. Rather, it is about the warped use your heart makes of it. ${ }^{13}$

Here we get further purchase on what Luther means by 'use'. 'Using', we discover, is something that the heart does. In other words, theologically speaking 'use' is first and foremost a matter of motivation. Idolatry is not primarily about objects in themselves; rather, it is to a significant degree about the psychology of the idolater. And the clue to understanding motivation, in Luther's view, is to look at how we feel about the object. To treat something as an idol, he tells us in the larger Galatians commentary, is to attach 'reverence' it, to take 'confidence' from it, to 'fear and respect' it. ${ }^{14}$ To 'use' something is thus in significant part to have a particular kind of affective relationship to it, to experience it a certain way.

Luther makes much the same point in the discussion of idolatry in the Large Catechism: 'To have a God ... does not mean to grasp him with your fingers' but to 'cling to him with your heart'. ${ }^{15}$ He gives the example of money: you know whether money is your god from how it makes you feel: if it makes you feel 'secure, happy, and fearless' when you have it, and 'despondent' and full of 'doubt and despair' when you do not, then money is a god to you. ${ }^{16}$

as a whole (a complex issue with which there is not enough space to engage here) there is little question that the later use/substance distinction develops out of the sort of thinking about substances that we see in the Dictata.

13 Non est disputatio de substantia, sed usu et abusu rerum. Non praedicamus, was das wesen an yhm selber sey. Sed de verkereten misbrauch tui cordis. Non cupimus mutari res, sed tuum cor perversum. WA 28:554.

${ }^{14}$ LW 26, pp. 92, 95; WA 40/I, pp. 170, 175. Luther makes the same point in the Large Catechism: "Idolatry does not consist merely of erecting an image and praying to it, but it is primarily a matter of the heart, which ... seeks help and consolation from creatures, saints, or devils': Martin Luther, The Large Catechism (Minneapolis: Fortress Press, 2000), p. 388.

15 Ibid.

${ }^{16}$ Ibid., p. 387. See also LW 2, pp. 325-8; WA 42, pp. 494-7. 
Luther goes on to apply this ethical principle to a wide variety of topics: to social positions and social roles; ${ }^{17}$ to sexual desire and marriage; ${ }^{18}$ to food, fasting and clothes; ${ }^{19}$ to images; ${ }^{20}$ and even to the sacraments. ${ }^{21}$ The core of his mature position is summarised in the Genesis lectures:

[T] he fault does not lie in those things that are good and are truly gifts of God but in the human beings who possess them and make use of them ... Let us see to it that the heart is right. Then everything will be right. ${ }^{22}$

17 'There must be masks or social positions, for God has given them, and they are His creatures. The point is that we are not to worship and adore them. The power is located in the use of things, not in the things themselves [In usu rerum, non in rebus ipsis vis sita est]' (LW 26, p. 95; WA 40/I, p. 174); trans. altered from the $L W$.

18 'Therefore he is not only a philosopher but a good theologian who does not condemn the things that God has given but condemns their use or control ... It is ... not evil to look at a woman, for woman is a good creature of God; but the fault is in your heart, because it desires a woman who is not yours' (LW 2, p. 328; WA 42, p. 496).

19 'Paul calls food and clothes and the like [in Col 2:22] outward things, usum rerum. He has not forbidden this use [Brauch]. He has only forbidden the evil desires that go with it. So you must distinguish these two, the use and the desire' (WA 9:614). This example from a 1521 sermon is a particularly early instance of Luther's deployment of the category of 'use'.

20 '[O]utward things' like images 'can do no harm to faith, if only the heart does not cleave to them or put its trust in them'. LW 51, pp. 83, 81-3; WA 10/III, pp. 29, 26-9. See also the discussion in Weimer, 'Justification in Word and Image', pp. 295-7.

21 As part of a larger discussion of the relationship between physical and spiritual eating of the Lord's Supper, Luther comments: 'Thus, "Spirit consists in the use, not in the object" [scilicet in usu, non in obiecto spiritus est] be it seeing, hearing, speaking, touching, begetting, bearing, eating, drinking, or anything else. For if a person serves his neighbor and does it physically, it is of no avail to him, for flesh is of no avail. But if he does it spiritually, i.e. if his heart does it out of faith in God's Word, it is life and salvation' (LW 37, p. 92; WA 23, p. 189).

${ }^{22}$ LW 2, p. 329; WA 42, pp. 496-7. Luther reiterates this claim later in the same section: "nature, which is corrupted by original sin, is unable to enjoy without abuse the things created and given by God, not because this is the nature of created things but because the heart of him who uses them is evil ... [But] he who believes, has everything, and is lord of all; he can make use of all things in a holy manner. [The difference comes] not from the nature of the things we use but from a difference in the heart' (LW 2, pp. 348-9; WA 42, pp. 510-11). Ebeling gives a helpful summary: 'uti and usus is for Luther the category of existential relation to an object' (Ebeling, 'On the Doctrine', 71). See also Luther's remarkable discussion in the 1538 Annotations on Matthew of the sayings about removing your eye or hand if it causes you to sin, where 'use' is interpreted in pneumatological terms: 'Therefore [Jesus] is speaking about the use of your members, not their substance. For the Spirit is in the use of the thing. What is the substance without the use, except death and nothing? [quid est substantia sine usu nisi mors et nihil] What is the hand if it does not do anything, and cannot do 


\section{'Use' and the practice of theological reasoning}

Significantly, Luther also applies this way of thinking to the task of theology itself, including the sorts of tasks we are involved in when as theologians we engage with past Christian tradition. Perhaps Luther's best-known deployment of the category of 'use' is in relation to what he calls the 'uses' of the law.

For Luther, theologically speaking the law of God has a very particular use, namely, to convict us of sin and to reveal the truth about ourselves and our need for God. As he puts it in his commentary on Galatians 3:19, 'Therefore the true function and chief and proper use of the Law is to reveal to man his sin, blindness, misery, wickedness, hate and contempt of God'. ${ }^{23}$ Although the connection is not often recognised, Luther does in fact explicitly connect 'use' in the ethical sense we examined in the previous section to this better known category of 'uses of the law'. The clearest example is in the Annotations on 1 Timothy:

[B]oth the wicked and the pious man have the Law. Both have a very good thing. But they disagree over its use ... We teach that one must use it correctly. Meat and fish are things, the created works of God. The only battle there is over their misuse ... [Meat and fish] were not created ... so that we might be justified by them, but that we might continue to live because of them ... Everything is good if one puts it to good use ... Use the Law as you wish ... Only keep this use away from it, that you credit it with the remission of sins and righteousness. ${ }^{24}$

Here, just as the problem is not with money or with meat in their substance, but with how they are used, so the significance of a given law of God is not adequately expressed or encompassed through its content. What is theologically decisive is how that content, that law, is being 'used'.

This explains why Luther believes that the same scriptural text can in principle be either law or gospel, depending on how it is heard, how it is used. As he explains in the Antinomian Disputations, what makes something 'law' is not so much its content as the affective and experiential effect it has on the sinner:

anything? It follows that life-giving or use is proper to the Holy Spirit [Spiritui sancto vivificatio seu usus]' (WA 60, p. 68).

${ }^{23}$ LW 26, pp. 309, 307-16; WA 410/I, pp. 480, 478-91.

${ }^{24}$ Luther continues: 'The Law, then, is very sacred, very fine; but it does not justify. It frightens, it accuses; but it does not justify and does not free one from death. If I credit a given created thing only with the things for which it was ordained, I do well. So the Law is abused when I assign to the Law more than it can accomplish' (LW 28, pp. 231-2; WA 26, p. 14). 
'[L]aw' ought not to be taken in a technical or material or grammatical sense, ... but as it ... sounds forth in your heart ... For the law is [an] experience or power ... [E] ven if you were to remove these letters: L-E-X, which can be very easily deleted, the handwriting etched into our hearts, which condemns and drives us, nonetheless remains. ${ }^{25}$

The upshot of this idea is that the form of language used is not enough to guarantee that a word will function as 'law'. For Luther, the use of the grammatical imperative does not necessarily make a word into 'law' in the theological sense unless it is heard as such; likewise, a word expressed in the indicative or subjunctive or interrogative mood can still be heard and experienced as 'law'. ${ }^{26}$ The consequence is that Luther's law-gospel distinction - in many ways the core principle at the heart of his soteriology - is in fact governed by dynamics of 'use'. It is how the law is experienced, how the heart perceives it and what the heart thinks it is doing with it, that is finally decisive in the law-gospel dynamic. '[A]s far as the words are concerned ... everyone can understand the distinction between law and grace; but so far as use, life, and affections are concerned [Sed in usu, vita, affectu], it is the most difficult thing there is. ${ }^{27}$

It follows from this that theologically speaking we have not understood even such straightforward texts as 'You shall not bear false witness' (Exod 20:16) until we have also taken into account how the text is heard and received at the level of affect and experience. If my heart hears those words and thinks 'if I do not lie, then God will love me and reward me', then it has distorted their theological meaning, and the law is being misused. If, instead, what is heard is 'I must not lie or deceive, and yet I can't seem to stop; woe is me, wretched man that I am', then it has been heard and used rightly. Thus the theological meaning and function of even a direct divine commandment cannot be fully known until it has been heard and experienced by particular people in particular contexts.

This, then, is what 'use' ultimately means for Luther: that the theological meaning of texts, claims and doctrines is always fluid until it becomes temporally, affectively and psychologically embedded in lives and in experience. For Luther it is only in the 'use' that the Spirit is decisively

25 Martin Luther, Solus Decalogus est Aeternus: Martin Luther's Complete Antinomian Theses and Disputations, trans. Holger Sonntag (Minneapolis: Lutheran Press, 2008), pp. 189-93.

26 Examples might include God's use of the interrogative in the garden ('Where are you?' Gen 3:9), or Nathan's use of the indicative to David ('You are the man!' 2 Sam 12:7).

${ }^{27}$ LW 26, p. 144; WA 40/I, p. 251; trans. altered from LW. 
involved. 'For the Spirit is in the use of the thing. What is the substance without the use, except death and nothing?'28

Crucially, this embedding in turn gives, inevitably, an ethical valence to a theological claim. As soon as the doctrine or tradition or object becomes something that is used and experienced, then it can be used rightly or wrongly, and it is vulnerable to idolatrous usurpation and misuse.

Before turning to the question of what this has to do with theological retrieval, there is a caveat that needs to be registered. We must not misunderstand what is happening here as a sheer rejection of substance in favour of 'use'. The prioritisation of 'use' over 'substance' is not some kind of motivational relativism, a simplistic reduction of meaning to subjectivity and positionality. You still need the actual doctrine or verse or object or tradition to 'use'. And that object will have a particular nature and character and content, in and of itself - a particular substance - that will to some degree shape how it can be used. For example, although Luther does apply his thinking on 'use' quite directly to the eucharist, ${ }^{29}$ nevertheless he still believes the Spirit requires actual bread and wine to use. The claim being made here, rather, is that the meaning of this substance is always simultaneously being lensed through the question of use. Getting the substance right - for example, doing good historical work to understand the meaning of a doctrine or verse in its original intended sense - remains important and indeed irreducible. But merely 'getting it right' is not yet enough. Theological claims can be true and yet still be used disastrously.

\section{Tradition and its 'use'}

Overall, the use/substance distinction is about Luther's development of an approach to theology that entails an ethical prioritisation of intention over substance. A consequence of this is that Luther affirms a kind of dynamic provisionality to theological claims, including claims that arise through our engagements with tradition.

In this his account has two key influences. The first is a particular thread in New Testament ethics. In articulating the use/substance distinction, to a significant degree Luther is building on the ethical equivalence that Jesus draws between intention and behaviour in the Sermon on the Mount (Matt $5: 21-2,27-8$ ), and especially on the elaboration of this theme that appears at various points in Paul as a way of reflecting on food offered to idols

${ }^{28}$ Quia Spiritus est usus rerum. Quia quid est substantia sine usu nisi mors et nihil? WA 60:68. See n. 22 above.

29 See e.g. his claim of the eucharist that 'The Spirit is in the use, not the object' (LW 37, p. 92; WA 23, p. 189). 
and on circumcision: the idea that 'all things are permissible but not all are beneficial' (1 Cor 10:23), the statement that 'no idol in the world really exists' because 'there is no God but one' (1 Cor 8:4) and, perhaps most clearly of all, the statement that 'nothing is unclean in itself, but it is unclean for anyone who thinks it is unclean' (Rom 14:14). Luther's use/substance distinction can be understood to a substantial degree as a reading of these passages in Paul. ${ }^{30}$

The second influence on Luther here is Augustine's discussion in De doctrina christiana of the distinction between 'use' and 'enjoyment' of an object (uti/frui) to understand the relationship between human beings and the created world. ${ }^{31}$ Luther demonstrates awareness of this distinction as early as the Lectures on Romans, and it is almost certainly the initial source of his own reflections on 'use'. ${ }^{32}$ According to Augustine, of all objects of our attention only God is to be enjoyed in and of himself; all other objects and signs are simply to be 'used', derivatively, towards the ultimate end of enjoyment of God. To enjoy an object in the world for its own sake rather than for God's sake is to commit idolatry by treating the object as God. As in Luther, these reflections on 'use' have significant implications for understanding the intrinsic significance of objects and signs. As Rowan Williams explains, in Augustine

The language of uti [use] is designed to warn against an attitude towards any finite person or object that terminates their meaning in their capacity to satisfy my desire, that treats them as the end of desire ... [This] entails that there is no finality, no 'closure' no settled or intrinsic meaning in the world we inhabit ... [We thus] live in a world of restless fluidities of meaning: all terms and all the objects they name are capable of opening out beyond themselves, coming to speak in a wider context, and so refusing to stay still under our attempts to comprehend or systematize or... idolize. $^{33}$

${ }^{30}$ In Luther's extended discussion of use and substance in the Lectures on Genesis, he refers directly to the relevant sections of Matt 5, 1 Cor 8 and 10, and Rom 14 (LW 2, pp. 328-9, 348; WA 42, pp. 497, 510-11). In the Galatians lectures he draws a similar point from 1 Cor 7:19 as well (LW 26, p. 92; WA 40/I, p. 170).

31 Augustine, De doctrina christiana 1.3-5, 20-1, 34-7.

32 See esp. the scholion on Rom 5:5 in LW 25, pp. 294-5; WA 56, p. 307. For a much later reference, see $L W 2$, p. 329; WA 42, p. 497.

33 Rowan Williams, 'Language, Reality, and Desire in Augustine's De Doctrina', Journal of Literature and Theology $3 / 2$ (1989), pp. 140-1. Williams continues: '[But] in the light of Christ, no res is left alone. It can be used, and so become a sign; it can mean what it is not' (pp. 141, 143). For a very helpful analysis of uti/frui in Augustine as well 
In Williams' interpretation of Augustine, the uti/frui distinction thus undergirds an assertion of the dynamic provisionality before God of all our concepts and interpretations that resonates closely with what we have found in Luther. Furthermore, also as in Luther, Augustine's distinction foregrounds the fundamental importance of the feeling, experiencing, 'using' subject in the production of meaning before God, since the difference between 'use' and 'enjoyment' occurs above all at the level of desire and affect.

It is important to note that Luther's affirmation of this dynamic provisionality of our theological engagements does not derive, as it often does for us moderns, from epistemological worries, but rather from concerns about the nature of sin. The theological troublemaker for Luther is not Kant or Hume, it is the Old Adam. ${ }^{34}$ This is why, in Luther's view, 'the proper subject of theology is man guilty of sin and condemned, and God the Justifier and Savior of man the sinner'. ${ }^{35}$ It is also why, for Luther, meaningful theological knowledge is always being lensed through soteriological dynamics, especially the relationship between law and gospel.

This approach to the task of theology does not deny the metaphysical importance of substances, but it does relativise it by viewing substance and propositional content as just one part of a dynamic system, a system in which theological meaning and theological claims are always, as Rowan Williams puts it, 'anchored in our temporal condition'. ${ }^{36}$ Theology's task is not exhausted in getting the doctrine right or in retrieving some idea or other from the Christian past, not by a long shot. For Luther as for Augustine, good theology has to be attentive to how doctrine, texts, and traditions are always being heard, used and experienced by human beings.

What can we conclude from this? For one, understanding this dynamic can help us to see how it is that Reformers like Luther and Calvin were deeply shaped by and attentive to traditional authorities and yet could claim, with Luther, that 'Scripture is to be preferred' to such authorities 'in every case' ${ }^{37}$ For example, it is well known that in the mid-1510s Luther came

as in Williams' interpretation of Augustine, see Susannah Ticciati, A New Apophaticism: Augustine and the Redemption of Signs (Leiden: Brill, 2013), esp. chs. 5 and 6.

34 Augustine, too, is concerned about sin and idolatry, but his account of 'use' is also tied very closely to the metaphysics of a Christian theology of creation in a way that, while by no means absent in Luther, is less at the forefront.

${ }^{35}$ LW 12, p. 311; WA 40/II, pp. 327a-328a.

36 'Language, Reality, and Desire', p. 142.

${ }^{37}$ LW 31, p. 262; WA 2, p. 8. For Calvin's engagement with the fathers as well as with scholastic theology, see Randall C. Zachman, John Calvin as Teacher, Pastor, and Theologian: The Shape of his Writings and Thought (Grand Rapids, MI: Baker Academic, 2006), pp. 83-6. 
to be influenced by claims he found in Augustine's anti-Pelagian writings about conscupiscence, about the relationship between baptism and sin, and about the correct reading of the 'divided-I' passage in Romans 7, with substantial impact on the development of the doctrine of justification by faith. ${ }^{38}$ In theory, Luther believed that his mature view on justification was based entirely on scripture, but in practice he is equally clear how important the discovery of Augustine's support was for him. ${ }^{39}$

In 'use' terms, this is a good example of how Luther was very happy to make 'use' of extra-biblical tradition in the development of doctrine - to engage in 'theological retrieval' himself - so long as he did not in the process come to view the authority of a figure like Augustine in an idolatrous way. The key issue in whether a given appeal to the fathers is legitimate is thus not whether your idea is formally resourced by an authoritative text, but rather how you perceive such resourcing. You can draw on the same text or idea either idolatrously - by imputing an authority to Augustine that should be reserved for the Bible alone - or non-idolatrously - by simply using him as a valuable but provisional authority from which to learn insofar as he is correct and helps us to understand scripture.

This dynamic helps explain why Luther, like Calvin, was not nearly as dogmatic about 'tradition', in practice, as the principle of sola scriptura appears to imply. To have established the substance of a tradition is not yet to have completed the task of retrieval - it must then be 'used' rightly as well. Ethically speaking, what is ultimately most decisive is not tradition as such but the use we make of it.

In seeking to understand the development of Luther's doctrine of justification, this lens allows us to see how things like how Luther felt about Augustine, i.e. how the figure of Augustine functioned psychologically for Luther, are in fact significant for understanding the theological dynamics here. For example, we might wonder whether Luther would have developed the courage of his convictions in relation to justification if he had not felt that he had a major patristic authority on his side. Augustine's antiPelagian writings thus did not just give the early Luther theological ideas to work with, they also gave him confidence. In table talk from the early 1530 s,

${ }^{38}$ For an excellent overview, see L'ubomír Batka, 'Sin', in Derek R. Nelson and Paul R. Hinlicky (eds), The Oxford Encyclopedia of Martin Luther, 3 vols. (Oxford: OUP, 2017), vol. 3, pp. 349-51; as well as Phillip Anderas, 'Augustine and Augustinianisms', ibid., vol. 1 , pp. 71-85.

39 In addition to the many citations of Augustine in the Lectures on Romans (see LW 48, pp. 24-5; WA BR 1, p. 70), Luther continues to speak positively about Augustine's views on sin and concupiscence throughout his life. See e.g. LW 34, pp. 185-7; WA 39/I, p. 116. 
Luther asserted that he no longer needed the authority of Augustine: 'Since I've come to understand Paul, I haven't paid attention to any doctor ... At first, I devoured Augustine ... But ever since the door into Paul was opened, and I knew what justification by faith was, it was out with him!'40 Understanding Luther's conception of 'use', we see why claims like this do not in fact undermine the practical dynamics by which Augustine served as a crucial stepping stone for Luther on the way to his formal trust in scripture alone, and indeed why Luther continued to cite Augustine in debates about concupiscence in the years after the table talk claim, for example in the 1536 'Disputation Concerning Justification'. ${ }^{41}$

Returning to contemporary theology, there are several further observations that can now be made. First, as I have argued, Luther's understanding of 'use' provides one valuable tool for thinking about dynamics of subjectivity and positionality in contemporary theology and in the retrievals that shape it. It draws our attention to psychological and affective dynamics in the practice of theology, and it gives us a method of understanding why theology's task is not exhausted in the putative procedure of getting a doctrine 'right' in historical or systematic terms. The use/substance distinction underscores how much it really does matter what we think we are doing with a tradition or doctrine, and how it really does matter how we go about communicating theological truth, not just whether we are correct.

Second, the reason that these dynamics matter is because they show how theology is always an ethically valenced enterprise. And this ethical valence goes beyond the single ethical pole of whether we are correct or incorrect in our articulation of a theological point. Luther's principle shows how theological discourse is also always subject to interrogation over whether or not idolatry is being committed, rather than just over whether deception or ignorance are in play.

Third, it is not difficult to see how this vision of theology as always caught up in ethical questions about motivation, affect and positionality might be deployed to resource theological interrogation of the non-explicit and often unconscious power dynamics involved in the act of theological reasoning. José Esteban Muñoz has written, for example, about the ways that 'whiteness' is a 'cultural logic that prescribes and regulates national feelings and comportment'. ${ }^{42}$ Luther's use/substance distinction gives us a

${ }^{40}$ LW 54, p. 49; WA TR 1, p. 140. The trans. here is taken from Anderas, 'Augustine and Augustinianisms', p. 79.

${ }^{41}$ LW 34, pp. 185-7; WA 39/I, p. 116.

42 José Esteban Muñoz, 'Feeling Brown, Feeling Down: Latina Affect, the Performativity of Race, and the Depressive Position', Signs $31 / 3$ (2006), p. 680. 
quite precise, and deeply Augustinian, method of analysing the relationship between affective economies like Muñoz is describing - in this case, how something like 'whiteness' functions in discourse as an implicit but powerful affective idolatry - and the practice of theology. ${ }^{43}$

By focusing our theological attention not just on what we say but how and why we say it, and on what it feels like to say it, the category of 'use' thus gives us a formidable tool for engaging theologically with forms of $\sin$ and pathology that are powerful but non-explicit. In relation to tradition, it gives us an instrument for showing how what we feel about a given theological tradition, and what a given act of theological retrieval does for us emotionally and as individuals and communities, and the dynamics involved in the conscious and subconscious motivations behind how we wield tradition, are factors of irreducible theological and ethical importance. They are fundamental to the question of whether a given theological retrieval or act of theological reasoning is idolatrous. Luther's distinction thus gives us a way of recognising the significance of the subjectivity of the theologian in theology by redescribing the practice of theology as one that is constantly caught up in dynamics of salutary use and idolatrous misuse.

Furthermore, as a matter of affect and motivation, the diagnostic power of the concept of 'use' does not stop with the individual. If we want to understand and assess what we desire and how we feel about objects and ideas we encounter, it is of course crucial that we attend to the fundamental issue of the disordered human heart and the irreducible role it plays in the generation of most particular pathologies. At the same time, however, it is also vital to we attend to the ways in which forces outside ourselves also draw and mould our desires, and shape which 'uses' are available to us in the first place, in the context of the broader affective economies in which we are always located.

The point, which deserves further elaboration elsewhere, can be demonstrated briefly in relation to money and financial ethics. As we have seen, Luther refers to money as a key example of a 'substance' where ethics are primarily determined by 'use'. But, as Kathryn Tanner demonstrated so persuasively in her 2016 Gifford Lectures, contemporary finance-dominated capitalism is expert at shaping and exploiting the affects of workers to generate profit. For example, the threat of being fired, articulated and justified as payroll cost-cutting in service of a cultural logic of profitgeneration, is an affective tool for 'induc[ing] worker compliance through

43 The same point could be made in relation to many further areas in ethics, e.g. the role of non-explicit and affective factors in sexism at both individual and cultural levels. 
fear'. ${ }^{44}$ Likewise, as Tanner argues, the chief purpose of something like the advertising industry is to generate and manipulate desires for goods, so as to induce workers into uncritical compliance with goals of corporations. As Tanner puts it, 'How can one criticize what have become the desires of one's own heart?' In both of these examples, desire and 'use' are substantially shaped by agents, forces and ideologies that we encounter in the world. Here we see an excellent instance of how attention to 'use' dynamics leads to analysis of the impact of structural forces as well as personal ones.

In this article, I have argued that theological retrieval, and ultimately theological reasoning itself, is an ethical drama that takes place before the God who knows the heart. Understanding this helps explain why, for Martin Luther, all theology goes back in the end to soteriological dynamics. ${ }^{45}$ Once we start paying attention to the heart, the sheer scale of 'misuse' in which we are involved, as perpetrators and also as victims, starts to become clear. Understanding our engagement with the world through the lens of 'use', we have a powerful tool for renarrating the pathologies of contemporary life in terms of Christian moral discourse about idolatry and sin. What might be the consequences of this resiting of moral discourse within a theological and hamartiological horizon? Such pathologies, now located within a long tradition of Christian reflection on the fallibility of human beings and the groaning of creation (Rom 8:22-3), may become a little less baffling to us. And old-fashioned theological topics like sin, forgiveness and the hope of redemption may start to look as urgently contemporary as they did in Luther's time.

${ }^{44}$ Quotations taken from the videos of Tanner's second and third Gifford Lectures currently on YouTube. Accessed Dec. 2017 <https://www.ed.ac.uk/arts-humanitiessoc-sci/news-events/lectures/gifford-lectures/gifford-lectures-2015-2016/ professor-tanner-christianity-and-capitalism/2-chained-to-the-past $>$ and $<$ https: //www.ed.ac.uk/arts-humanities-soc-sci/news-events/lectures/gifford-lectures/ gifford-lectures-2015-2016/professor-tanner-christianity-and-capitalism/ 3-total-commitment>.

45 'The proper subject of theology is man guilty of sin and condemned, and God the Justifier and Savior of man the sinner' (LW 12, p. 311; WA 40/II, pp. 327a-328a). 